\title{
Gamma-Aminobutyric Acid Receptor Subunit Alpha-6
}

National Cancer Institute

\section{Source}

National Cancer Institute. Gamma-Aminobutyric Acid Receptor Subunit Alpha-6. NCI

Thesaurus. Code C147971.

Gamma-aminobutyric acid receptor subunit alpha-6 (453 aa, $\sim 51 \mathrm{kDa}$ ) is encoded by the human GABRA6 gene. This protein is involved in ligand-gated chloride transport. 